\title{
An Analytical Study of Strawberry Crop in Egypt
}

\section{Shehata, Hala M.A.; M.A. Soliman and Dina M. Ewis}

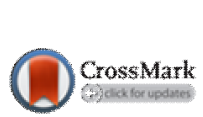

Agriculture Economics Dept., Faculty of Agriculture, Minia University, Egypt

Received on: $27 / 8 / 2020$

Accepted for publication on: 7/9/2020

\section{Abstract}

The study aims to investigate the production, consumption, and exportation of strawberry crop during the period (2000-2018) through studying the determinants of strawberry's crop production in Egypt, Examining the consumption of strawberry, and calculating marketing margins for it. The average cultivated area of strawberry crop during the period (2000-2018) was about 13.36 thousand Feddan, with an average productivity of about 15.04 ton / Feddan, while the total production was about 212.41 thousand tons. Meanwhile, the annual average available for consumption, The average per capita and selfsufficiency ratio were about 189.70 thousand tons, 22.71 thousand ton, $2.21 \mathrm{~kg} /$ year, $110,81 \%$ on the ranking during the Study period with a statistically significant increasing.

The annual average price of the product of strawberry during the Study was about 1.99 pounds $/ \mathrm{kg}$, and the annual average of the price of a strawberry was about $2.98 \mathrm{EGP} / \mathrm{kg}$, and the average annual retail price of strawberries was about $3.97 \mathrm{EGP} / \mathrm{kg}$.

The annual amount of exports of strawberry has increased Significantly by an annual amount, about 5.04 thousand ton, or represents $11.51 \%$ from The average amount of strawberry exports which amounting 43.80 thousand ton during the same period. The annual value of strawberry exports also has increased by Significantly, by 6049.4 thousand dollar, represents about $1360 \%$ of the average value of exports of strawberries, (44475.37 thousand dollar) during the same period.

Keywords: Strawberry, amount of exports, Egypt.

\section{Introduction:}

The export in Egypt is one of the most important sectors that contributes in the economic development, and the main sources of foreign trade. However, Egypt has suffered from a growing deficit in its trade balance for decades. Therefore, promoting Egyptian exports will reduce the trade deficit and achieve economic development goals.

Among all agricultural export crops, strawberry is considered one of the non-traditional exports. This crop is cultivated in a wide range of soils, including the newly reclaimed lands and, therefore, it does not compete with the main crops on old lands in the Nile valley and the total value of strawberry exports mounted has amounted about 73.77 million dollars in 2018 compared to 188.52 thousand dollars in 2000 .

\section{The Problem of the study:}

Strawberry is considered one of the most important non-traditional Egyptian export crop that may contribute in reducing the trade deficit and, thus, the achievement of economic development. However, Egyptian agricultural exports, including strawberries, face many challenges 
including production and marketing challenges that limit the country's ability to export.

\section{The Objectives:}

The study aims to investigate the production, consumption, and export of strawberry crop during the period (2000-2018) through the determinants of strawberry's crop production in Egypt, examining the consumption of strawberry, and calculating marketing margins of strawberry during the same period.

\section{Methodology and Tools of analysis:}

The study depends on both descriptive and analytical tools through time series data covered the period from (2000-2018) were collected from different sources, suitable statistical analysis were used to achieve its objectives. And study the growth rate of the production and consumption of strawberry crop in Egypt.
Strawberry's data that is used in this study are collected from sources the Central Agency of Public Mobilization and Statistics, CAPMAS, (www.capmas.gov.eg); the Ministry of Agriculture and Land Reclamation in Egypt, MALR.

Results:

1- The production of strawberry in Egypt:

Table 1 shows the production of strawberry in Egypt during the period $(2000$ - 2018) the area planted in strawberry has significantly increased in recent years. On the average, the average cultivated area of strawberry crop was 13.36 thousand feddans during the period (2000-2018) Since 2000 , strawberry plantings grew from 6.40 thousand feddans in 2000 and 21.04 thousand feddan in 2018, increased by $229 \%$ of the total area of strawberry in 2000.

Table 1. The area, production and productivity of strawberry crop in Egypt during the period $(2000-2018)$.

\begin{tabular}{|c|c|c|c|}
\hline Year & $\begin{array}{c}\text { Area } \\
\text { (thousand feddan) }\end{array}$ & $\begin{array}{l}\text { Total Production } \\
\text { (thousand ton) }\end{array}$ & $\begin{array}{c}\text { Yield } \\
\text { (ton/feddan) }\end{array}$ \\
\hline 2000 & 6.40 & 70.612 & 11.03 \\
\hline 2001 & 6.43 & 68.137 & 10.6 \\
\hline 2002 & 5.757 & 60.017 & 10.43 \\
\hline 2003 & 7.312 & 79.771 & 10.91 \\
\hline 2004 & 9.134 & 104.971 & 11.49 \\
\hline 2005 & $12 . .032$ & 157.279 & 13.07 \\
\hline 2006 & 10.201 & 128.349 & 12.58 \\
\hline 2007 & 15.059 & 174.414 & 11.58 \\
\hline 2008 & 12.458 & 200.254 & 16.07 \\
\hline 2009 & 13.722 & 242.776 & 17.69 \\
\hline 2010 & 12.488 & 238.432 & 19.09 \\
\hline 2011 & 13.4 & 240.284 & 17.93 \\
\hline 2012 & 13.889 & 242.297 & 17.45 \\
\hline 2013 & 14.061 & 262.432 & 18.66 \\
\hline 2014 & 15.498 & 283.471 & 18.29 \\
\hline 2015 & 22.822 & 435.342 & 19.03 \\
\hline 2016 & 22.835 & 378.96 & 16.6 \\
\hline 2017 & 19.243 & 318,95 & 16.58 \\
\hline 2018 & 21.04 & 348.955 & 16,59 \\
\hline Average & 13,36 & 212.41 & 15.04 \\
\hline
\end{tabular}

Source:

Agricultural Economics Bulletin, Economic Affairs Sector, Ministry of Agriculture and Land Reclamation. 
Table 2 shows the estimation of trend of cultivated annual area, yield, and total production of strawberry during the period (2000-2018) Using equation (1), the area cultivated of strawberry has increased significantly during the period (2000-2018). The annual growth rate of the area was $6.5 \%$ of the average. Moreover, the coefficient of determination was about $85 \%$ in the area cultivated of strawberry.

Table 2. Estimation of growth rate of area, production and productivity of strawberry crop in Egypt during the period (2000 - 2018).

\begin{tabular}{|c|c|c|c|c|c|c|c|}
\hline $\begin{array}{c}\text { Equation } \\
\text { number }\end{array}$ & Variable & Equation & $R^{2}$ & $\mathbf{F}$ & Mean & Change & $\begin{array}{c}\text { Rate Change } \\
(\%)\end{array}$ \\
\hline (1) & $\begin{array}{c}\text { Area } \\
\text { (thousand feddan) }\end{array}$ & $\begin{array}{r}\mathrm{y}=4.678+0.868 \mathrm{x} \\
(9.89) * *\end{array}$ & 0.852 & $97.81 * *$ & 13.36 & 0.868 & 6.50 \\
\hline (2) & $\begin{array}{l}\text { Strawberry pro- } \\
\text { ductivity (tons } \\
\text { /feddan) } \\
\end{array}$ & $\begin{array}{c}\hat{y}=10.185+0.485 x \\
(6.17) * *\end{array}$ & 0.691 & $38.06^{* *}$ & 15.04 & 0.485 & 3.22 \\
\hline (3) & $\begin{array}{c}\text { Total production } \\
\text { (thousand ton) }\end{array}$ & $\begin{array}{r}\hat{y}=24.642+18.78 x \\
(12.38) * *\end{array}$ & 0.900 & $153.26 * *$ & 212.41 & 18.78 & 8.84 \\
\hline
\end{tabular}

Where:

$\hat{y}$ : Estimated value of the variable in year $t$

$X_{i}$ : years from $i=1$ to $i=19$

Values between parentheses refer to $t$ values.

$*$ indicates Significance at 0.05 level and $* *$ indicates Significance at 0.01 level.

As shown in Table 1, the average productivity per unit of land planted of strawberry was about 15.04 ton per feddan during the period (2000-2018), the strawberry yield has increased from 11.03 ton per feddan in 2000 to 16.59 ton per feddan in 2018. The rate of increase was $15.04 \%$ of the average yield of strawberry in 2000 Furthermore, it ranged from a minimum of 10.43 tons per feddan in 2002 and a maximum of 19.00 tons per feddan in 2010 .

Growth rate of the yield of strawberry using equation (2) has increased significantly during the period (2000-2018). The rate of change was $3.22 \%$ of the average. Moreover, the coefficient of determination shows that time is responsible for $69 \%$ of the variance in the yield of strawberry.

The total production of strawberry has increased from 70.61 thousand ton in 2000 to 348.96 thousand ton in 2018. On average, the rate of increase was $394.2 \%$ of the total production in 2000 average quantity produced of strawberry was about 212.41 thousand ton during the study period, ranged from a minimum of 60.02 thousand ton in 2002 and a maximum of 435.34 thousand ton in 2015.

Furthermore, the growth rate of total production strawberry using equation (3) has increased during the period (2000-2018). The total production of strawberry significantly increased annually by $8.84 \%$ of the average. Moreover, the coefficient of determination shows that time is responsible for $90.00 \%$ of the variance in the total production of strawberry.

2-The consumption of strawberry crop in Egypt:

A- Available for consumption of strawberry:

By studying the development of strawberry consumption in Egypt during the period (2000-2018), Table (3) that it ranged between a minimum 
of about 57.747 thousand ton in 2002, and a maximum of about 410.745 thousand ton in 2015 , with an annual average of about 189.70 thousand ton.

By estimating the trend for consumption of strawberries in Egypt during that period, it was found from equation (1) in Table (4) that the linear function is the best function whose results showed that there is increase in the amount of consumption of strawberry, it was 16,561 ton /feddan it represents $8.73 \%$ of the average. The average amount is about 189.70ton/feddan, as the determination factor is about 0,849 , i.e., about $85 \%$ of the changes occurring in the availability of strawberry consumption are due to the time and the remaining in due to the factors are not studied.

\section{B - Surplus of strawberries:}

By studying the strawberry surplus in Egypt during the period
(2000-2018), it shows that from Table (3) that it ranged between a minimum of about 0.34 thousand tons in 2000, and amaximum of about 74.628 thousand ton in 2011, with an annual average of about 22.71 thousand ton.

By estimating the equation of the general time trend of the surplus of strawberry in Egypt during that period, it shows from equation No. (2) in Table No. (4), that the linear function is the best function, whose results show that there is a significant increase in surplus of strawberry Ton/feddan, and it represents about $9.75 \%$ of the annual average of about 22.71 Ton/feddan, as the determination coefficient was estimated at 0.321 , meaning that about $32 \%$ of the changes in the surplus of strawberries are due to factors that are reflected in the time element, while $68 \%$ of the other factors.

Table 3. The production, consumption and the percentage of self-sufficiency of strawberry crop in Egypt during the period (2000-2018).

\begin{tabular}{|c|c|c|c|c|c|c|}
\hline Years & $\begin{array}{l}\text { Total production } \\
\text { (Thousand ton) }\end{array}$ & $\begin{array}{c}\text { Available for con- } \\
\text { sumption } \\
\text { (Thousand ton) } \\
\end{array}$ & $\begin{array}{c}\text { Surplus } \\
\text { Thousand ton }\end{array}$ & $\begin{array}{l}\text { Population (mil- } \\
\text { lion) }\end{array}$ & $\begin{array}{c}\text { Average per } \\
\text { capita (kg / year) }\end{array}$ & $\begin{array}{c}\text { Self- } \\
\text { sufficiency\% }\end{array}$ \\
\hline 2000 & 70.612 & 70.275 & 0.34 & 68.832 & 1.02 & 100.48 \\
\hline 2001 & 68.137 & 66.897 & 1,24 & 70.153 & 0.95 & 101.85 \\
\hline 2002 & 60.017 & 57.747 & 2,27 & 71.485 & 0.81 & 103.93 \\
\hline 2003 & 79.771 & 76.948 & 2,82 & 72.826 & 1.06 & 103.67 \\
\hline 2004 & 104.971 & 101.526 & 3,45 & 74.172 & 1.37 & 103.39 \\
\hline 2005 & 157.279 & 154.227 & 3.05 & 75.524 & 2.04 & 101.98 \\
\hline 2006 & 128.349 & 115.74 & 12.61 & 76.874 & 1.51 & 110.98 \\
\hline 2007 & 174.414 & 152.801 & 21.61 & 78.232 & 1.95 & 114.14 \\
\hline 2008 & 200.254 & 190.971 & 9.28 & 79.636 & 2.40 & 104.86 \\
\hline 2009 & 242.776 & 175.794 & 66.98 & 81.135 & 2,17 & 138.10 \\
\hline 2010 & 238.432 & 220.919 & 17.51 & 82.761 & 2,67 & 107.93 \\
\hline 2011 & 240.284 & 165.656 & 74.63 & 84.529 & 1,96 & 145.05 \\
\hline 2012 & 242.297 & 219.35 & 22.95 & 86.422 & 2,54 & 110.46 \\
\hline 2013 & 262.432 & 229.219 & 33.21 & 88.405 & 2,59 & 114.49 \\
\hline 2014 & 283.471 & 228.722 & 54.75 & 90.425 & 2,53 & 123.94 \\
\hline 2015 & 435.344 & 410.745 & 24.60 & 92.443 & 4.44 & 105.99 \\
\hline 2016 & 378.96 & 349.17 & 29.79 & 94.447 & 3,70 & 108.53 \\
\hline 2017 & 318.95 & 295.301 & 23.65 & 96.443 & 3.06 & 108.01 \\
\hline 2018 & 348.955 & 322.231 & 26.72 & 98.424 & 3.27 & 108.29 \\
\hline Average & 212.41 & 189.70 & 22.71 & 82.272 & 2.21 & 110.81 \\
\hline
\end{tabular}

Collected and calculated from Ministry of Agriculture and Land Reclamation, Agricultural Economics department Bulletin, Economic Affairs Sector, Central Administration for Agricultural Economics, Miscellaneous Issues. 
Table 4. Equations of the general time trend of the available development of production and consumption and the percentage of self-sufficiency in strawberry crop in Egypt during the period (2000-2018).

\begin{tabular}{|c|c|c|c|c|c|c|c|c|}
\hline $\begin{array}{c}\text { Equation } \\
\text { number }\end{array}$ & Sample & Phenomenon & The equation & $\begin{array}{l}\text { The coeffi- } \\
\text { cient of } \\
\text { determina- } \\
\text { tion }\end{array}$ & $\begin{array}{c}\text { Value } \\
\text { of(f) cal- } \\
\text { culated }\end{array}$ & Average & $\begin{array}{c}\text { Amount } \\
\text { of } \\
\text { change }\end{array}$ & \begin{tabular}{|c|} 
Rate \\
of \\
change \\
$\%$
\end{tabular} \\
\hline (1) & $\begin{array}{l}\text { Linear } \\
\text { Function }\end{array}$ & $\begin{array}{l}\text { Available for } \\
\text { consumption } \\
\text { (Thousand } \\
\text { tons) }\end{array}$ & $\begin{aligned} \hat{y}= & 24,082+16,561_{x} \\
& (9,79) * *\end{aligned}$ & .0894 & $95.91 * *$ & 189.70 & 16.561 & 8.73 \\
\hline (2) & $\begin{array}{c}\text { Linear } \\
\text { Function }\end{array}$ & \begin{tabular}{|c} 
Surplus \\
Thousand tons
\end{tabular} & $\begin{array}{c}\mathrm{y}=0,560+2.215_{\mathrm{x}} \\
(2,84) *\end{array}$ & 0.321 & $8.04 *$ & 22.71 & 2.215 & 9.75 \\
\hline (3) & $\begin{array}{c}\text { Linear } \\
\text { Function }\end{array}$ & $\begin{array}{l}\text { Population } \\
\text { (million) }\end{array}$ & $\begin{aligned} \mathrm{y}= & 11.13 \times 0.020 \mathrm{e} \\
& (88.8) * *\end{aligned}$ & 0.998 & 78.90 & 82271.87 & - & $2 \%$ \\
\hline (4) & $\begin{array}{l}\text { Linear } \\
\text { Function }\end{array}$ & $\begin{array}{c}\text { Average per } \\
\text { capita (kg / } \\
\text { year }\end{array}$ & $\begin{array}{c}\hat{y}= \\
(8,36) * *\end{array}$ & 0.804 & $69.807 * *$ & 2.213 & 0.156 & 7.04 \\
\hline (5) & $\begin{array}{l}\text { Quadratic } \\
\text { Function }\end{array}$ & $\begin{array}{c}\text { Self- } \\
\text { sufficiency } \%\end{array}$ & $\begin{array}{l}\mathrm{y}=90.26+4.78 \mathrm{x}-0.206 \mathrm{x}^{2} \\
(2.56) * \quad(-2.27) *\end{array}$ & 0.318 & $3.73 *$ & 110.81 & 0.66 & 0.60 \\
\hline
\end{tabular}

\section{Where:}

$y=$ indicates the estimated value of the phenomenon under study during the period (2000-2018).

$\mathrm{x}=$ denotes time $(1,2,3, \ldots, 19)$.

The value in parentheses is the calculated value of $(\mathrm{t}) . *$ Significant at level of significance $0.05, * *$ significant at level of significance 0.01 .

The annual change amount was calculated from the second-degree equations as follows (by varying the equation and compensating for the value of (x) by the average of the total years of study).

Source: - calculated from the data of Table No. (4) Thesis.

\section{C- Population:}

By studying the evolution of the population in Egypt during the period (2000-2018), it was found from Table No. (3) that it ranged between a minimum of about 68.8 million people in 2000, and a maximum of about 98.4 million people in 2018 , with an average amount about 82.3 million people.

By estimating the general time trend equation for the strawberry population in Egypt during that period it was noticed, from equation No. (3) in Table No. (4), that the growth rate of population was 0.020 thousand people and it represents about $2 \%$ from the average of population.

\section{D- Average Per Capita Strawberry Share:}

By studying the evolution of the per capita strawberry share in Egypt during the period (2000-2018), it shows that from Table (3) that it ranged from a minimum of about $0.18 \mathrm{~kg} /$ person in 2002 , and a maximum of about $4.44 \mathrm{~kg} /$ person in 2015 , with an average of about 2.21 $\mathrm{kg} /$ person.

By estimating the trend of the average per capita strawberry share in Egypt during that period, from equation No. (4) in Table No. (4), it is shown that the linear function is the best Function.

It was noticed that, the average per capita strawberry crop has increased significantly estimated by about $2.21 \mathrm{kilogram} /$ year, i.e.

The coefficient of determination was about 0.804 , this means about $80.4 \%$ of changes accurse in per cap- 
ita was due to changes in time and the reaming in due to other factors.

\section{E -Strawberry Self-Sufficiency:}

By studying the development of self-sufficiency of strawberry crop in Egypt during the period (2000-2018), it noticed from Table No. (3) that it ranged between a minimum percentage of about $100.48 \%$ in 2000 , and a maximum percentage of about $145.05 \%$ in 2011., With an annual average of about $110.81 \%$.

The growth rate of selfsufficiency of strawberry in Egypt during that period, equation No. (5) in Table No. (4) it showed, the quadratic function is the best estimate function, which results showed that, The growth rate of the selfsufficiency of strawberry crop has increased significantly by 0.66 and the rate of change was $0.60 \%$ during the study period, The determination coefficient was about 0.318 , i.e., about $31.8 \%$ of the of changes in the average per-capita due to the changes in time and the reaming due to other factors not studied.

\section{3- Marketing margins and distribu- tion of consumer pounds of straw- berry crop in Egypt:}

\section{1- The price of the strawberry product:}

By studying the evolution of the product price of strawberries in Egypt during the period (2000-2018), Table No. (5) showed that it ranged between a minimum value of about 1.27 pound/ $\mathrm{kg}$ in 2005, and a maximum of about 3.83 pound/ $\mathrm{kg}$ per year. 2018 , with an average annual value of about 1.99 pound $/ \mathrm{kg}$. By estimating the equation of the general time trend for the price of the strawberry's prod- uct in Egypt during the period (20002018), it showed from equation No. (1), Table No. (6).

That the linear Function is the best function and the price of strawberries has increased significantly during the study period, it was about 0.119 pound $/ \mathrm{kg}$, it represented $5.95 \%$ of the annual average, (1.99 pound/ $\mathrm{kg}$,) and the determination coefficient was about 0.775 , meaning that about $77.5 \%$ of the changes in the price of the product is due to factors that are reflected by, while $22.5 \%$ of the changes due to other Factors.

2- The strawberry wholesale price:

By studying the evolution of the wholesale price of strawberries in Egypt during the period (2000-2018), Table No. (5) shows that, it ranged between a minimum of about 1.37 pound/ $\mathrm{kg}$ in 2005, and a maximum of about 7.45 pound $/ \mathrm{kg}$ a year. 2018 with an average annual rate of about 2.98 pound $/ \mathrm{kg}$.

With an estimate of the general trend formula of strawberry wholesale price in Egypt during the period (2000-2018), equation No. (2) in Table No. (6), has was shown that the linear Function is the best estimated function, and whose results showed a statistically significant increase in the wholesale price of the strawberry crop, it was about 0.227 pound/ $\mathrm{kg}$, it represented $9.13 \%$ of the annual average, which amounted to 2.98 pound $/ \mathrm{kg}$, and the determination factor was about 0.777 , meaning that about $77.7 \%$ of the changes in the wholesale price of strawberry are due to the factors of time, while $22.3 \%$ of the changes are due to other factors. 
Website:www.aun.edu.eg/faculty_agriculture/journals_issues_form.php E-mail:ajas@aun.edu.eg

Table 5. Estimation of the average product price, wholesale price and retail price of strawberry crop in Egypt during the period (2000-2018).

\begin{tabular}{|c|c|c|c|}
\hline Years & $\begin{array}{c}\text { Producer price } \\
\text { (pound) }\end{array}$ & $\begin{array}{c}\text { Wholesale price } \\
\text { pound / kg }\end{array}$ & $\begin{array}{c}\text { Retail price } \\
\text { pound / kg }\end{array}$ \\
\hline 2000 & 1.31 & 1.41 & 2.00 \\
\hline 2001 & 1.37 & 1.50 & 1.97 \\
\hline 2002 & 1.37 & 1.47 & 2.13 \\
\hline 2003 & 1.50 & 1.60 & 2.46 \\
\hline 2004 & 1.72 & 1.92 & 2.94 \\
\hline 2005 & 1.27 & 1.37 & 1.88 \\
\hline 2006 & 1.31 & 1.69 & 2.24 \\
\hline 2007 & 1.39 & 2.19 & 2.75 \\
\hline 2008 & 1.51 & 2.93 & 3.82 \\
\hline 2009 & 1.53 & 2.18 & 3.24 \\
\hline 2010 & 1.63 & 2.11 & 2.85 \\
\hline 2011 & 2.31 & 2.79 & 3.95 \\
\hline 2012 & 2.36 & 3.01 & 4.05 \\
\hline 2013 & 2.41 & 3.85 & 5.23 \\
\hline 2014 & 2.45 & 4.18 & 5.71 \\
\hline 2015 & 2.56 & 4.07 & 5.52 \\
\hline 2016 & 2.58 & 4.30 & 5.75 \\
\hline 2017 & 3.51 & 6.59 & 8.04 \\
\hline 2018 & 3.83 & 7.45 & 8.90 \\
\hline average & 1.99 & 2.98 & 3.97 \\
\hline
\end{tabular}

Source: - Collected and calculated from:

1. Ministry of Agriculture and Land Reclamation, Agricultural Economics Bulletin, Economic Affairs

Sector, Central Administration for Agricultural Economics, different volumes.

2. The FAO website www.Fao.org.

\section{3- The retail price of strawberries:}

By studying the evolution of the retail price of strawberries in Egypt during the period (2000-2018), Table No. (5) shows that it ranged between a minimum value of about 1.88 pound $/ \mathrm{kg}$ in2005, and a maximum value of about 8,90 pound/ $\mathrm{kg}$ a year in 2018 , with an annual average of about 3.97 pound $/ \mathrm{kg}$.

Table 6. General time trend equations of the evolution of the average product price, wholesale price and retail price of strawberry crop in Egypt during the period (2000-2018).

\begin{tabular}{|c|c|c|c|c|c|c|c|c|}
\hline $\begin{array}{c}\text { Equation } \\
\text { number }\end{array}$ & Sample & Phenomenon & The equation & $\begin{array}{c}\text { The coeffi- } \\
\text { cient of de- } \\
\text { termination }\end{array}$ & $\begin{array}{c}\text { Value } \\
\text { of(f) cal- } \\
\text { culated }\end{array}$ & Average & $\begin{array}{c}\text { Amount } \\
\text { of } \\
\text { change }\end{array}$ & $\begin{array}{c}\text { rate } \\
\text { Change } \\
\text { \% }\end{array}$ \\
\hline$(1)$ & Linear & $\begin{array}{c}\text { Producer price } \\
\text { pound / } \mathrm{kg}\end{array}$ & $\mathrm{y}=0,804+0,119 \mathrm{x}$ & 0.775 & $58.55^{* *}$ & 2.00 & 0.119 & 5.95 \\
\hline$(2)$ & Linear & $\begin{array}{c}\text { Wholesale } \\
\text { price } \\
\text { pound / } \mathrm{kg}\end{array}$ & $\begin{array}{r}\mathrm{y}=0,652) * * \\
(7.701) * *\end{array}$ & 0.777 & $59.31 * *$ & 2.98 & 0.272 & 9.13 \\
\hline$(3)$ & Linear & $\begin{array}{r}\text { Retail price } \\
\text { pound / } \mathrm{kg}\end{array}$ & $\begin{array}{r}\mathrm{y}=0,664+0,331 \mathrm{x} \\
(8.695) * *\end{array}$ & 0.816 & $75.61 * *$ & 3.97 & 0.331 & 8.34 \\
\hline
\end{tabular}

Where:

$\hat{y}=$ indicates the estimated value of the phenomenon under study during the period (2000-2018).

$\mathrm{x}=$ denotes time $(1,2,3, \ldots, 19)$.

The value in parentheses is the calculated value of $(\mathrm{t}) . *$ Significant at level of significance $0.05, * * \quad$ significant at level of significance 0.01 .

Source: - Collected and calculated from the data of Table No. (6) in the study. 
By estimating the general time trend of the retail price of strawberries in Egypt during the period (20002018), from equation No. (3) in Table No. (6), the linear Function is the best function. whose results showed a statistically significant increase in the retail price of the strawberry, it was 0.331 pound $/ \mathrm{kg}$, it represented about $8.34 \%$ of the annual average (3.97 pound $/ \mathrm{kg}$ ), the determination coefficient was 0.816 this means about $81.6 \%$ of the changes in the retail price are due to factors that reflected the element of time, while $19.4 \%$ of the changes due to other factors.

\section{4- Strawberry Marketing Margins:}

By studying the evolution of the absolute and relative marketing margins between the price of the product and the wholesale price of the strawberry crop in Egypt during the period (2000-2018), it noticed from Table No. (7), that it ranged between a minimum amount of about 0.01 pound/ $\mathrm{kg}$ in 2000, 2002, 2003 In 2005 , with a percentage representing about $7.09 \%, 6.83 \%, 6.27 \%$, and $7.31 \%$ of the price of the product, respectively, a maximum of about 3.62 pound/ $\mathrm{kg}$ in 2018, it representing $48.59 \%$., The average of these differences during this period was about $0.98 \mathrm{pound} / \mathrm{kg}$, representing about $20.76 \%$ of the average price of the product.

Table No. (7) also shows the absolute and relative marketing margins between the retail price and the wholesale price of the strawberry crop in Egypt during the study period, ranging between the lowest value of about 0,473 pound/ $\mathrm{kg}$ in 2001, it represented about $24.03 \%$ of the wholesale price, and a maximum value of
About 1.53 pound/ $\mathrm{kg}$ in 2014, representing about $26.80 \%$, and the average year for these differences during this period was about 0.99 pound/ $\mathrm{Kg}$, it represents about $25.97 \%$ of the overall average wholesale price.

Table No. (7) also shows the absolute and relative marketing margins between the retail price and the price of the product for the strawberry crop in Egypt during the study period, ranged between the lowest price of about 0.60 pound/ $\mathrm{kg}$ in 2001 , it representing about $30.64 \%$ of the product price, and a maximum price about 5,07 pound / $\mathrm{kg}$ in 2018, it represents about $56.97 \%$ from the average year of these differences during this period was about 1.98 pound/ $\mathrm{kg}$, which represents about $45.24 \%$ of the average price of the product.

- The producer's share of the consumed pound of strawberries:

Table (7) shows the share of the product from the consumption pound it was 39.47 pound in 2008 , and the maximum amount about 69.36 pound in 2001, with an annual average about $53.01 \%$.

- Wholesaler's share of the consumed pound of strawberries:

It has shown from Table No. (7) that the share of the wholesaler in the distribution of the consumed pound reached the minimum in 2003 and it was about 4.07 pound, while the maximum amount was about 40.67 pound in 2018, with an annual average of about $15.23 \%$.

- The retailer's share of the consumed pound of strawberries:

It has shown from Table No. (7) that the retailer's share in the distribution of consumer pounds has reached the minimum in 2018, it was about 
16.29 pound, while the maximum amount about 35.03 pounds in 2003 , with an average annual rate about $25.97 \%$.

\section{- Brokers' share of strawberry pounds consumed:}

Table (7) showed that the share of intermediaries from the distribu- tion of the consumed pound reached the minimum level in 2001 and it was about 30.64 pound, while the maximum amount about 60.53 pound in 2008 , with an average annual rate of about $45.24 \%$.

Table 7. Evolution of the product price, wholesale, retail, and marketing margins of strawberry crops in Egypt during the period (2000-2018).

\begin{tabular}{|c|c|c|c|c|c|c|c|c|c|c|c|c|c|}
\hline \multirow{3}{*}{ Years } & \multirow{3}{*}{$\begin{array}{c}\text { The price } \\
\text { of the } \\
\text { product } \\
\text { pound / kg }\end{array}$} & \multirow{3}{*}{$\begin{array}{c}\text { Wholesale } \\
\text { price } \\
\text { pound / kg }\end{array}$} & \multirow{3}{*}{$\begin{array}{l}\text { Retail price } \\
\text { pound / kg }\end{array}$} & \multicolumn{6}{|c|}{ Marketing differences or margins } & \multicolumn{4}{|c|}{ Distribution of consumer pounds\% } \\
\hline & & & & \multicolumn{2}{|c|}{$\begin{array}{c}\text { (Wholesale - } \\
\text { producer ) }\end{array}$} & \multicolumn{2}{|c|}{$\begin{array}{c}\text { (retail - } \\
\text { wholesale) }\end{array}$} & \multicolumn{2}{|c|}{$\begin{array}{c}\text { (retail - } \\
\text { producer) }\end{array}$} & \multirow{2}{*}{$\begin{array}{c}\text { Product } \\
\text { share }\end{array}$} & \multirow{2}{*}{$\begin{array}{c}\text { Wholesaler } \\
\text { share }\end{array}$} & \multirow{2}{*}{$\begin{array}{c}\text { Share } \\
\text { of } \\
\text { retailer }\end{array}$} & \multirow{2}{*}{$\begin{array}{c}\text { The share } \\
\text { of } \\
\text { intermediaries }\end{array}$} \\
\hline & & & & Divorced & Rate & Divorced & rate & Divorced & Rate & & & & \\
\hline 2000 & 1.31 & 1.41 & 2.00 & 0.10 & 7.09 & 0.585 & 29.32 & 0.69 & 34.34 & 65.66 & 5.01 & 29.32 & 34.34 \\
\hline 2001 & 1.37 & 1.50 & 1.97 & 0.13 & 8.70 & 0.473 & 24.03 & 0.60 & 30.64 & 69.36 & 6.61 & 24.03 & 30.64 \\
\hline 2002 & 1.37 & 1.47 & 2.13 & 0.10 & 6.83 & 0.665 & 31.22 & 0.77 & 35.92 & 64.08 & 4.69 & 31.22 & 35.92 \\
\hline 2003 & 1.50 & 1.60 & 2.46 & 0.10 & 6.27 & 0.86 & 35.03 & 0.96 & 36.10 & 60.90 & 4.07 & 35.03 & 39.10 \\
\hline 2004 & 1.72 & 1.92 & 2.94 & 0.20 & 10.42 & 1.018 & 34.65 & 1.22 & 42.46 & 58.54 & 6.81 & 34.65 & 41.46 \\
\hline 2005 & 1.27 & 1.37 & 1.88 & 0.10 & \begin{tabular}{|l|}
7.31 \\
\end{tabular} & 0.512 & 27.23 & 0.61 & 32.55 & 67.45 & 5.32 & 27.23 & 32.55 \\
\hline 2006 & 1.31 & 1.69 & 2.24 & 0.38 & 22.22 & 0.55 & 24.58 & 0.93 & 41.33 & 58.67 & 16.76 & 24.58 & 41.33 \\
\hline 2007 & 1.39 & 2.19 & 2.75 & 0.80 & 36.58 & 0.558 & 20.31 & 1.36 & 49.45 & 50.55 & 29.15 & 20.31 & 49.45 \\
\hline 2008 & 1.51 & 2.93 & 3.82 & 1.42 & 48.41 & 0.898 & 23.49 & 2.31 & 60.53 & 39.47 & 37.04 & 23.49 & 60.53 \\
\hline 2009 & 1.53 & 2.18 & 3.24 & 0.65 & 30.00 & 1.06 & 32.72 & 1.71 & 52.90 & 47.10 & 20.19 & 32.72 & 52.90 \\
\hline 2010 & 1.63 & 2.11 & 2.85 & 0.48 & 22.65 & 0.74 & 25.96 & 1.22 & 42.74 & 57.26 & 16.77 & 25.96 & 42.74 \\
\hline 2011 & 2.31 & 2.79 & 3.95 & 0.49 & 17.38 & 1.16 & 29.37 & 1.65 & 41.65 & 58.35 & 12.28 & 29.37 & 41.65 \\
\hline 2012 & 2.36 & 3.01 & 4.05 & 0.65 & 21.63 & 1.04 & 25.68 & 1.69 & 41.75 & 58.25 & 16.07 & 25.68 & 41.75 \\
\hline 2013 & 2.41 & 3.85 & 5.23 & 1.44 & 37.48 & 1.38 & 26.39 & 2.82 & 53.98 & 46.02 & 27.59 & 26.39 & 53.98 \\
\hline 2014 & 2.45 & 4.18 & 5.71 & 1.73 & 41.44 & 1.53 & 26.80 & 3.26 & 57.13 & 42.87 & 30.33 & 26.80 & 57.13 \\
\hline 2015 & 2.56 & 4.07 & 5.52 & 1.51 & 37.17 & 1.45 & 26.27 & 2.96 & 53.68 & 46.32 & 27.41 & 26.27 & 53.68 \\
\hline 2016 & 2.58 & 4.30 & 5.75 & 1.72 & 40.07 & 1.45 & 25.22 & 3.17 & 55.18 & 44.82 & 29.97 & 25.22 & 55.18 \\
\hline 2017 & 3.51 & 6.59 & 8.04 & 3.08 & 46.80 & 1.45 & \begin{tabular}{|l|}
18.03 \\
\end{tabular} & 4.53 & 56.39 & 43.61 & 38.36 & 18.03 & 56.39 \\
\hline 2018 & 3.83 & 7.45 & 8.90 & 3.62 & 48.59 & 1.45 & \begin{tabular}{|l|}
16.29 \\
\end{tabular} & 5.07 & 56.97 & 43003 & 40.67 & 16.29 & 56.97 \\
\hline average & 1.99 & 2.98 & 3.97 & 0.98 & 20.76 & 0.99 & 25.97 & 1.98 & 45.24 & 53.01 & 15.23 & 25.97 & 45.24 \\
\hline
\end{tabular}

* Percentages with a geometric mean

Sources: - 1. Ministry of Agriculture and Land Reclamation, Agricultural Economics Bulletin, Economic Affairs Sector, Central Administration for Agricultural Economics, separate numbers.

2. The FAO website www.Fao.org.

5 -Evolution of the quantity and value of exports and the export price of the strawberry crop in Egypt during the period (20002018):

1- Evolution of the amount of strawberry exports:

A study of the evolution of the amount of strawberry exports in Egypt during the period (2000-2018) revealed from Table No. (8) that it ranged between a minimum of about 0.83 thousand ton in 2000 and a maximum of about 143.01 thousand ton in 2014, While the average amount of exports was about 43.80 thousand ton during the same period.

In estimating the general time trend equation for the quantity of exports of strawberries in Egypt during (2000-2018), it noticed from equation No. (1) in Table No. (9) that the linear function is the best function. The quantity strawberry exports about 5.04 thousand ton, i.e. it represents $11.51 \%$ of the average amount of exports of strawberries, which amounts to about 43,80 thousand ton during the same period, as the coefficient of determination was estimated at 0.400 , 
i.e. about $40 \%$ of the quantity of strawberry exports due to time While $60 \%$ of the changes are due to other factors.

\section{2- The development of the value of strawberry exports:}

By studying the development of the value of strawberry exports in Egypt during the period (2000-2018), it was noticed from Table No. (8) that, they ranged between a minimum value of about 189 thousand dollar in 2000 , and a maximum value of about 98331 thousand dollar in 2016, while the average The value of exports is about 44475.37 thousand dollar during the same period.

With an estimate of the general time trend equation for the value of exports of strawberry in Egypt during (2000-2018), from equation No. (2) in Table No. (9), it was shown that the best estimated function is the linear function and the results showed that there is a statistically significant increase in the value of exports Strawberries, amounted to about 6049.4 thousand dollar, it represented $13.60 \%$ of the average value of exports of strawberries, (44475.37 thousand dollar during the same Period), as defined by about 0816 plants, ie estimated that about $81.6 \%$ of the changes occurring in the value of exports of strawberries due to factors that are reflected in the element of time, while $18.4 \%$ of the changes due to other causes.

Table 8. Evolution of the quantity, value and price of exports of strawberry crops in Egypt during the period $(2000-2018)$.

\begin{tabular}{|c|c|c|c|}
\hline Years & Quantity (thousand ton) & $\begin{array}{c}\text { the value } \\
\text { (Thousand dollar) }\end{array}$ & $\begin{array}{c}\text { price } \\
\text { (Dollar) }\end{array}$ \\
\hline 2000 & 0.83 & 189 & 228 \\
\hline 2001 & 1.24 & 319 & 257 \\
\hline 2002 & 2.27 & 893 & 393 \\
\hline 2003 & 2.82 & 1469 & 521 \\
\hline 2004 & 3.44 & 2120 & 616 \\
\hline 2005 & 3.05 & 1739 & 570 \\
\hline 2006 & 12.68 & 6348 & 501 \\
\hline 2007 & 21.61 & 12040 & 557 \\
\hline 2008 & 71.16 & 52234 & 734 \\
\hline 2009 & 78.12 & 86601 & 1109 \\
\hline 2010 & 91.77 & 64935 & 708 \\
\hline 2011 & 74.98 & 58697 & 783 \\
\hline 2012 & 29.55 & 76821 & 2600 \\
\hline 2013 & 33.55 & 69253 & 2064 \\
\hline 2014 & 143.01 & 76969 & 538 \\
\hline 2015 & 39.29 & 72418 & 1843 \\
\hline 2016 & 138.63 & 98331 & 709 \\
\hline 2017 & 40.61 & 89864 & 2213 \\
\hline 2018 & 43.56 & 73774 & 1694 \\
\hline Average & 43.80 & 44475.37 & 980.95 \\
\hline
\end{tabular}

Source:

collected and calculated from: Central Agency for Public Mobilization and Statistics - Foreign Trade Database -Unpublished data-Cairo2018. 
Table 9. General time trend equations for the evolution of the quantity, value and price of exports of strawberry crop in Egypt during the period $(2000$ - 2018).

\begin{tabular}{|c|c|c|c|c|c|c|c|c|}
\hline $\begin{array}{c}\text { Equation } \\
\text { number }\end{array}$ & Sample & Phenomenon & The equation & $\begin{array}{c}\text { The coefficient } \\
\text { determination }\end{array}$ & $\begin{array}{c}\text { Value (f) } \\
\text { calculated }\end{array}$ & Average & $\begin{array}{c}\text { Amount } \\
\text { of } \\
\text { change }\end{array}$ & $\begin{array}{c}\text { rate } \\
\text { Change } \\
\text { \% }\end{array}$ \\
\hline $\mathbf{( 1 )}$ & Linear & $\begin{array}{c}\text { Quantity } \\
\text { (thousand } \\
\text { ton) }\end{array}$ & $\begin{array}{r}\mathrm{y}=-6.56+5.04 \mathrm{x} \\
(3.36) * *\end{array}$ & 0,400 & $11.31^{* *}$ & 43.80 & 5.04 & 11.51 \\
\hline $\mathbf{( 2 )}$ & Linear & $\begin{array}{c}\text { the value } \\
\text { (Thousand } \\
\text { dollar) }\end{array}$ & $\begin{array}{c}\mathrm{y}=-16018+6049.4 \mathrm{x} \\
(8.69)^{* *}\end{array}$ & 0.816 & $75.46^{* *}$ & 44475.37 & 6049.4 & 13.60 \\
\hline
\end{tabular}

Where:

$\hat{y}=$ indicates the estimated value of the phenomenon under study during the period (2000-2018).

$\mathrm{x}=$ denotes time $(1,2,3, \ldots, 19)$.

$\square$ rate of change $=$ (amount of annual change $\div$ average value) $\times 100$

Source: Calculated from data of Table No. (8).

\section{Recommendations:}

1- Attention to trading and postharvest operations to reduce waste and benefit more with local consumption and export.

2- Paying attention to the various marketing operations of the strawberry crop to raise the per capita share and reduce the share of brokers.

3- Working to increase the cultivated area, especially as it can be cultivated in new, sandy, light and yellow lands.

4- Working to increase feddan productivity of the strawberry crop.

\section{References}

Central Agency for Public Mobilization and Statistics, annual bulletin for the prices of food products and materials. Separate years.

Doaa Hussein, Ibrahim Mahmoud, Fayrouz Ahmed and Abdel-Malik Ahmed (2019). Determinants of strawberry production in Beheira Governorate and post-harvest transactions according to international quality standards, AlMansoura Magazine for Agricultural Economics and Social Sciences, Volume 10 , No. (7).

FAO website www.Fao.organistation.

Iman Salem Al-Batran (2016). Determinants of the Competitiveness of Egyptian Strawberry Exports in the Most Important Global Markets, Mansoura Journal of Agricultural Economics and Social Sciences, Volume 7, Number 7.

Ministry of Agriculture and Land Reclamation, Agricultural Economics Bulletin, Economic Affairs Sector, Central Administration of Agricultural Economics, different volumes.

Tariq Ali and Ahmed Abdullah (2017). Standard Analysis and Future Prediction of Economic Factors Affecting Strawberry Exports, Assiut Journal of Agricultural Sciences, Volume (48), No. 3. 


\section{دراسة تمليلية لمحصول الفراولة في مصر}

\section{هاله محمد علي شحاتة، مكادي عبد المجيد سليمان ودينا ممدوح عويس}

قسم الاقتصاد الزر اعي_ كليه الزر اعة جامعه المنيا- مصر

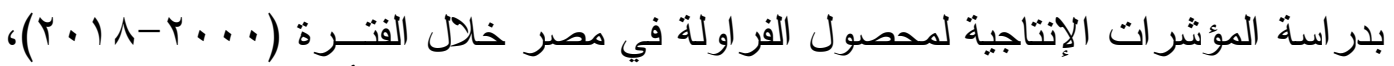

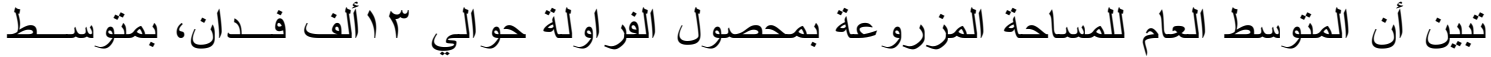

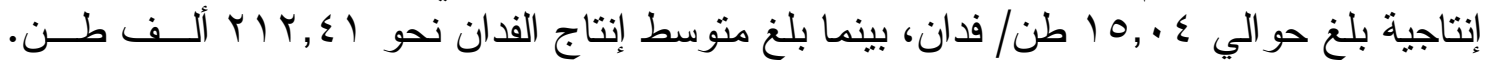

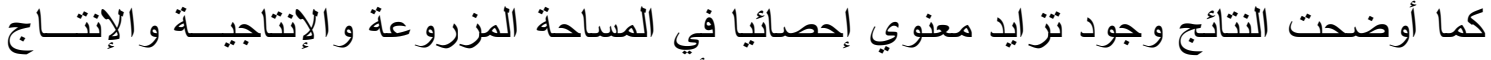

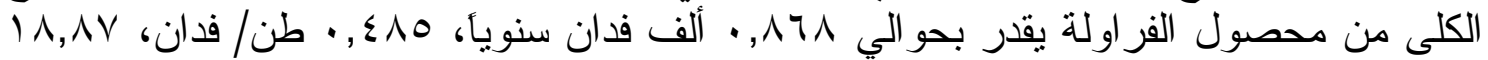
ألف طن/ فدان على التزتيب.

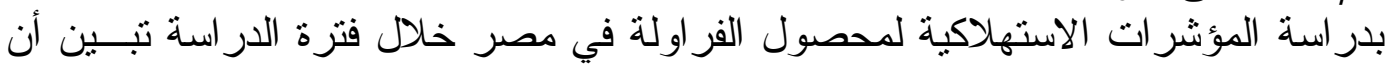

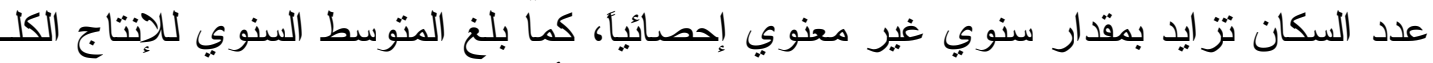

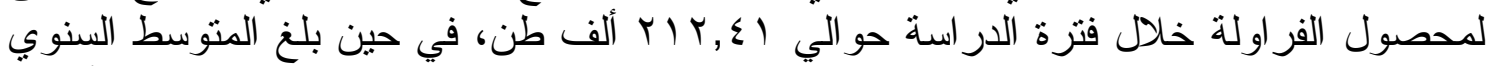

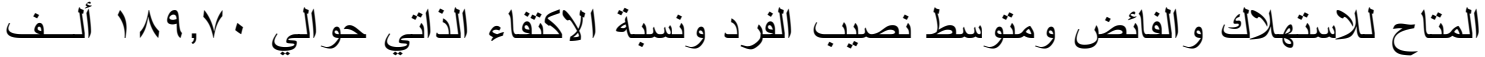

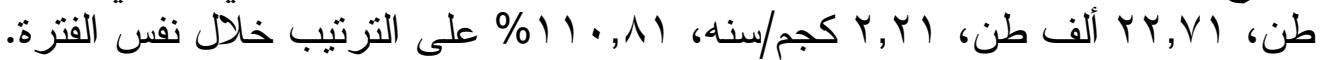

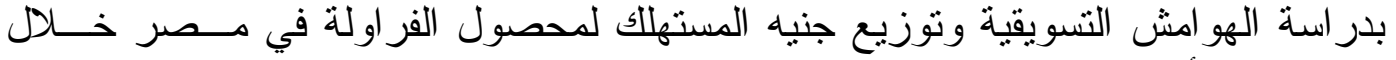

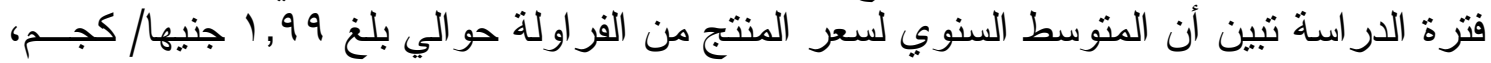

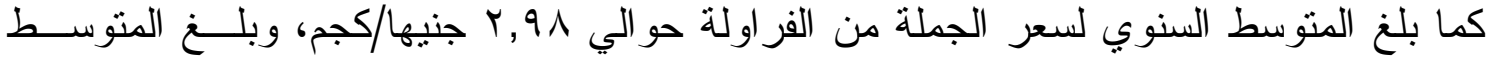

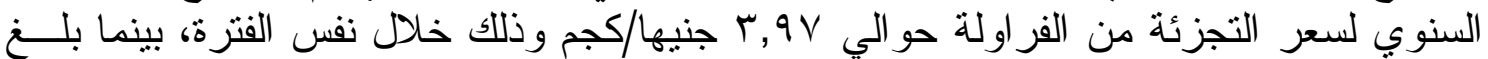

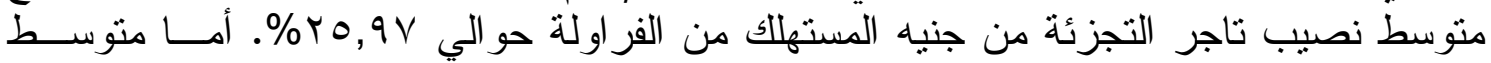

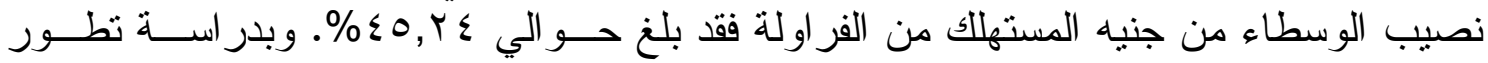

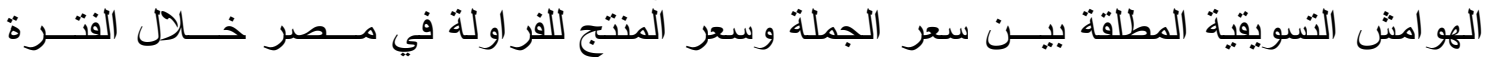

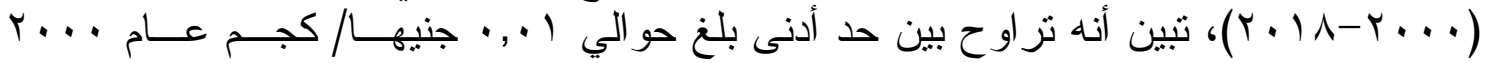

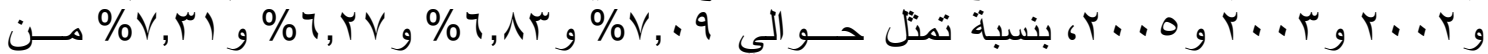
سعر المنتج على الترتيب.

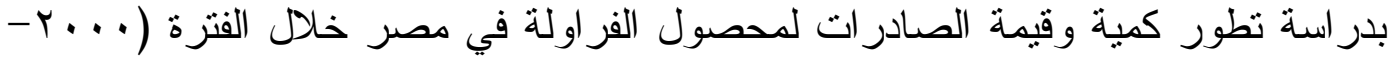

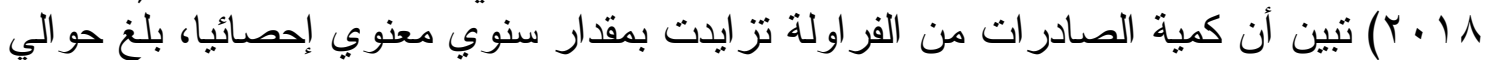

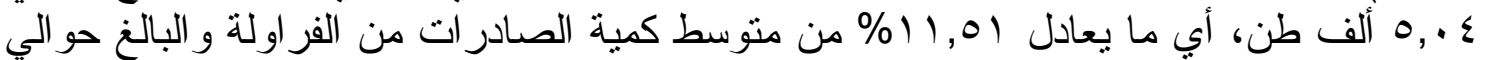

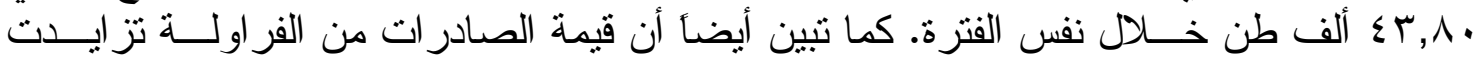

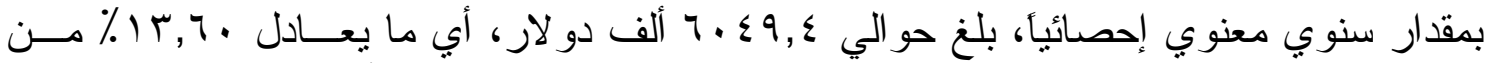

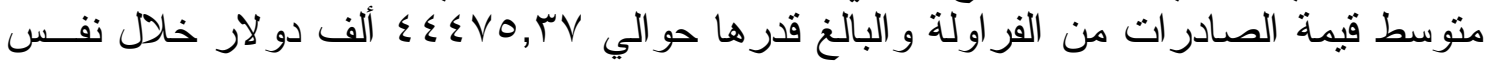

